\title{
Gender and Globalisation: Labour Changes in the Global Economy*
}

\author{
MARTA KOLÁŘOVÁ** \\ Institute of Sociology, Academy of Sciences of the Czech Republic, Prague
}

\begin{abstract}
The article focuses on gender aspects of globalisation and global restructuring and criticises the masculine bias of mainstream theories of globalisation. It is aimed at adding a global dimension to Czech gender studies. It looks at the way in which globalisation is gendered and based on gender ideologies, and how global restructuring affects and change gender systems. Primarily economic globalisation is addressed, and the changes in the organisation of labour globally are examined. Global production is dependent on cheap women's labour in the factories of multi-national corporations in the global south. The process of rendering labour more flexible and informal is associated with its feminisation. Care work and migration are also becoming feminised on a global scale. The article also analyses domestic work performed in the United States and Western Europe by women migrants from developing countries. All these processes are occurring within the context of neo-liberal policies and the changing role of states amidst a global restructuring, which needs to be examined from a gender perspective.
\end{abstract}

Keywords: gender, globalisation, production, domestic work, migration

Sociologický časopis/Czech Sociological Review, 2006, Vol. 42, No. 6: 1241-1257

\section{Introduction}

Theories of globalisation in sociology, economics, or international relations usually leave gender aspects aside. Feminist theorists argue that gender inequalities in the global world are not taken into account [Pyle and Ward 2003]. This is particularly true of Czech theories of globalisation [see Mezřický 2003]. Not only is gender analysis missing in this book, but women are only mentioned once, in the biological context of the global problem of a population explosion. Publications on globalisation by non-Czech authors translated into Czech do not focus on gender aspects either [e.g. Giddens 2000]. However, as Peterson and Runyan [1999] argue, gender is an important perspective in the analysis of globalisation. It identifies global

\footnotetext{
* Acknowledgements: This research was made possible by a Fulbright scholarship. I would like to thank Dr. Ethel Brooks of Rutgers University for helpful comments on earlier drafts.

** Direct all correspondence to: Marta Kolárová, Institute of Sociology, Academy of Sciences of the Czech Republic, Jilská 1, 11000 Prague 1, Czech Republic, Marta.Kolarova@soc.cas.cz
}

(C) Sociologický ústav AV ČR, Praha 2006 
agents, characterises state and non-state activities, and creates a framework for global issues and thinking about possible alternatives to globalisation.

The omission of gender from mainstream globalisation theories goes hand in hand with masculine dominance in this scholarship. Bergeron [2001] and Freeman [2001] have shown that in particular macro-structural models, 'grand narratives', and theories of globalisation are masculine. I would argue that this is surprising given that global studies is a new field that emerged in academia several decades after gender studies (at least in the West). Therefore, the reasons for omitting gender must be deeply rooted deeply in social theory in general.

The gender bias has given rise to a dichotomous model of the global and the local: global and related theory is associated with masculinity and being mobile, fluid, cosmopolitan, and modern; while the local and ethnographic is tied to femininity and static, homebound, and traditional characteristics [Freeman 2001]. Marchard and Runyan [2000] criticise the globalisation discourses as gender biased. Some institutions, sectors, agents or processes are valued more (for instance, the market over the state, the global over the local), and these are associated with masculinity. What is characterised as feminine is considered less important. The hierarchies and inequalities are maintained through a strong gender symbolism that makes global restructuring seem natural and unavoidable.

In earlier feminist ethnographies, gender was mostly analysed empirically, focusing on the impact of globalisation on locality and women's lives. However, feminist scholars have recently addressed globalisation theoretically, and Freeman [2001] argues that many feminist studies do address the macro and micro aspects of globalisation.

Publications focusing on gender and globalisation mainly address economic globalisation. Their authors analyse the changes in production, new forms of women's employment, women's activism aimed at improving working conditions, 'care' services or domestic work, and migration. Other aspects of globalisation, such as politics and culture, are examined less. These issues, which are analysed elsewhere, appear to lie outside the discourse on gender and globalisation, which is mostly economically oriented.

According to Marchard and Runyan [2000] and Pyle and Ward [2003] global processes change gender systems, roles, and relations and strengthen gender inequalities, but they are also rooted in a gendered reality and gendered ideologies. Therefore, gender influences globalisation, and globalisation reinforces gender formations. The processes of globalisation are fused with gender ideologies. "Contemporary forms of globalization are themselves deeply imbued with specific notions about femininity and masculinity and expectations for the roles of women and men." [Freeman 2001: 8] But at the same time globalisation processes are altering gender systems and quashing the dichotomies of the masculine and feminine world by bringing more and more women into formerly male-dominated spheres, especially production and migration [Freeman 2001]. Consequently, new forms of femininity are evolving. As Walby [1997] points out, femininity is not defined just by 
motherhood or domesticity any more. The participation of women in traditionally male domains on the one hand changes the forms of masculinity and men's roles and on the other threatens men by taking 'their' jobs. The reaction is to try and reestablish traditional patriarchal systems, which can result in increased violence against women.

I want to look at the point where gender studies and globalisation studies intersect. Not just the gender aspects of globalisation are neglected, but, in Czech gender studies, globalisation processes and global society is not addressed. When labour and gender are the focus of Czech gender studies, then all that is ever examined is the Czech situation and the country's experience in the post-communist transformation in comparison with other East European countries. ${ }^{1}$ I see this as a limitation, because global processes and neo-liberal politics affect Czech society, too. In addition, it is important to know what consequences these processes have in other locations. Incorporating global issues into Czech gender studies brings up other inequalities for consideration, particularly class and race/ethnicity. These are often neglected, while the differences between men and women, without other characteristics, are usually examined.

In this paper I want to answer the following related questions: How are the theories of globalisation gendered? How is globalisation gendered? What changes affecting labour globally are associated with gender? And, from the opposite perspective, what kind of impact do globalisation processes have on gender systems, relations, and roles? How are women and men affected by globalisation?

\section{The theory of economic globalisation and gender}

Stiglitz [2002: ix] defines globalisation as the "removal of barriers to free trade and the closer integration of national economies". Bhagwati [2004: 3] adds to the definition "direct foreign investment (by corporations and multi-nationals), short-term capital flows, international flows of workers and humanity generally, and flows of technology". A definition of economic globalisation put out by the International Monetary Fund [2002] stresses "the growing economic interdependence of countries worldwide through increasing volume and variety of cross-border transactions in goods and services, free international capital flows, and more rapid and widespread diffusion of technology". The IMF, together with other international institutions, such as the World Bank, multi-national corporations, and the governments of powerful states (G8) are regarded as the major players in globalisation [Mezrický 2003].

Most gender scholars are critical of the 'malestream' globalisation theories and projects and criticise them for focusing on impersonal flows and not on real people. Feminist scholars especially address the impact of globalisation on women, for ex-

\footnotetext{
1 The transition from state socialism to capitalism in the context of globalisation has only been analysed by a non-Czech scholar - True [2003].
} 
ample, analysing the effects of structural adjustment programmes on women's lives [Rai 2002; Starr 1994]. According to these authors, local lifestyles are important because they put a real face on the very remote processes of globalisation. Aquilar and Lacsamana [2004], for instance, put emphasis on material conditions in contrast to flows of information that are stressed in mainstream theories.

A major part of gender scholarship is focused on global inequalities. Gender inequalities in the global world are especially striking: "Women compose one-half of the world's population and perform two-thirds of the world's work hours, yet are everywhere poorer in resources and poorly represented in positions of decisionmaking power." [Peterson and Runyan 1999: 5] As these authors argue, in the global society, women are excluded from the positions of power, both economic and political. Furthermore, women make up about $80 \%$ of all refugees and $70 \%$ of the illiterate population. Afshar and Barrientos [1999] argue that the world is ruled by male elites that benefit most from the new global order.

This gendered international division of power, labour, and wealth is not new, but globalisation has increased inequalities between both countries and individuals. The transfer of capital and investment to production in Third World countries has altered the international division of labour, even from the perspective of gender. Export production in the global south and migration to the global north has been feminised primarily owing to globalisation processes.

Gender scholars explain that globalisation in not an inevitable and irreversible process, as some of its proponents argue, and they instead see globalisation as a construct. For instance, Rai sees the problem in the 'naturalisation' and 'depolitisation' of globalisation, interpreting it as "the product of the invisible hand of the global market" [Rai 2002: 9]. Globalisation is criticised for being a predominantly neo-liberal project based on a pro-free market ideology. This critical stance explains why most scholarship on gender and globalisation focuses on the economy, labour, capitalism, and markets and their impact on women.

\section{Women, gender, feminism, and masculinity in globalisation}

Most publications on gender and globalisation use the word 'gender' and/or 'women' in their titles; however, those that use the word 'women' focus mostly on women's work and describe how globalisation processes influence women's lives and how it is women who bear the burden of cuts to social spending. This scholarship is usually based on ethnographies focusing on various individual locations in the global production network, migration, and care work; for instance Women Reinventing Globalization [Kerr and Sweetman 2003], Women and Globalization [Aquilar and Lacsamana 2004], Globalizovaná žena (The Globalised Woman) [Wichterich 2000].

Although feminists maintain that women are more negatively affected by globalisation processes than men, they show that not all women are victims of globalisation and not all men are winners. They also analyse the differences and inequalities 
among women, based on class, race/ethnicity, and place in the global economy. Many women in the global north are in advantageous positions; they are free from housework and childcare. However, globally this work still rests on women, especially poor immigrant women, who are hired to fulfil these functions in developed countries.

Scholars writing about gender usually address more complex changes in gender systems (e.g. The Gendered Politics of Economic Globalization [Ramamurthy 2001]). These authors stress that it is not only important to 'add women' to the theory of globalisation, but the relations between men and women globally and the changes to gender systems as a result of globalisation must also be addressed [Walby 1997]. Benería [2003] argues that just studying women is not enough. Globalisation affects and changes gender regimes; it does not just affect women alone [Kelly et al. 2001].

Globalisation processes create two dichotomous areas from a gender perspective: one is the world of global finance and post-modern individualism associated with Western capitalist masculinity; the other is based on gendered and racial subordination and low-paid, unskilled labour, which is associated with women [Momsen 2004]. Enloe [1990] has pointed out that these two spheres are interdependent. Masculinised domains of global high politics and finance are tied to feminised cheap labour. Without unpaid and low-paid women's work, the global economy would not function. She argues: "keeping women's labour cheap requires vigilance and daily effort. That effort is an integral part of what is called 'international political economy'". [Enloe 1990: 166]

Those scholars that use the word feminism in the study of globalisation usually focus on social change and women's or feminist activism [e.g. Rowbotham and Linkogle 2001]. Some authors focusing on gender and globalisation also write about men and masculinities; however, this scholarship usually remains separate from studies on women and globalisation.

Theorists in the field of men's studies show how globalisation is changing masculinities and how men and masculinities are shaping global processes. Connell [1998] has analysed globalising masculinities using the terms 'neo-liberal masculinity' and 'trans-national business masculinity'. "The hegemonic form of masculinity in the current gender order is the masculinity associated with men who control the world's dominant institutions: the business executives who operate in global markets and the political executives who interact and in many contexts merge with them." [Connell 1998: 16] Connell argues that the hegemonic global masculinities of businessmen and politicians are characterised by a flexible, calculating egocentrism, no sense of responsibility for others, no stable commitments, technical rationality, and open sexuality. This gendered description not only applies to a specific group of men, but also to the institutions in the international arena, such as markets and trade, politics, and neo-liberalism.

Danner and Young [2003] call these two contemporary forms of hegemonic masculinity 'Davos Man' and 'Big Brother'. Davos Man represents global elite business masculinity. Big Brother is militant and surveillant masculinity, re-invented after 9/11, in the era of the global war on terrorism. These two models can be at odds, but they 
work well together in both arenas of globalisation: neo-liberal economic restructuring and military dominance and security. Benería [2003] also uses the term Davos Man, by which she means not just businessmen and bankers, but also officials and intellectuals who share a belief in individualism, market economics, and democracy. Rai [2002] in this context uses the concept of 'hypermasculinity' that dominates feminised society.

Kimmel [2003] analyses how the global hegemonic model of masculinity is opposed by local or national oppressed men men who are trying to strengthen their masculinity and support local patriarchal structures. While rejecting globalisation and the spread of Western or multi-cultural values, they try to subordinate 'their' women and relegate them to a traditional social status. Here he particularly cites the examples of the neo-Nazi nationalist movements and the Islamist men of Al Qaeda.

\section{Economic globalisation and women's productive work}

Globalisation has opened up markets, but, as Rai [2002] argues, not all markets have been deregulated in the same way. Finances may flow freely throughout the world, but the flow of human labour is restricted. Both of these markets are gendered: the trade and finance worlds are masculine, and the labour markets are now becoming increasingly feminised by the large-scale entry of women into the workforce. "Globally, women own about 1 per cent of the world's property; therefore, they are involved in the globalization process through their access to labour markets rather than through their participation in financial or investment markets. They are the providers of services - sexual, domestic and increasingly as workers in export production - and are employed in lower-paid work; they are not in control of the huge financial and export flows in a globalized economy." [Rai 2002: 98] Women, and poor women in the global south in particular, are entering the marketplace not to seek a profit, but because they are struggling to survive. There has been a significant rise in women's employment in the past fifty years, from $46 \%$ in 1950 to $81 \%$ in 2000 worldwide, and it has occurred mostly in relation to export production [Rai 2002]. On the other hand, this form of production has led to an increase in the demand for flexible and cheap labour, which is a feminised domain [Afshar and Barrientos 1999]. Flexible and informal labour has been rendered so in connection with its feminisation [Ramamurthy 2001].

The opening up of markets in the global south encouraged multi-national corporations to build their factories there, particularly in Latin America and South-East Asia. The development of the economies in Third World countries is facilitated by a growing export industry, especially textiles and electronics. Mostly women are employed in these 'export processing zones' (EPZs) because they can be paid less than men.

Many authors have shown that multi-national companies prefer women, because they believe that women are best suited to these jobs - being docile, young, 
and often from a rural background in developing countries, and they have nimble fingers, are willing to accept low wages, and are patient enough to perform monotonous work [Benería 2003; Renzetti and Curran 2003]. Corporations also benefit from women's lower status, their efficiency, and their non-participation in unions. Pyle and Ward [2003] argue that the global production and trade are dependent on women's labour, both in the formal and the informal sectors. Global actors deliberately use gender stereotypes to their own advantage, as in many cultures women's income is understood as supplementary to that of the male breadwinner. The rising number of working single mothers is not given consideration. Corporations count on the fact that women in poor countries have few other options to earn money. Global production and its effects on labour are an example of how globalisation is tied up with gender and particular notions of femininity and masculinity.

There are about four million people working in export factories in fifty countries around the world, and most of them are young women (this does not include informal work). Momsen [2004] took Malaysia as an example to show how employing young female workers is more profitable for corporations. Young female employees between the age of sixteen and twenty are more disciplined, naïve, and obedient than older women. Also, they are usually not married, which means that their time is more flexible than that of married women with children. In addition, employers can pay them just $58 \%$ of men's wages. These women work $50 \%$ more hours than women doing the same work in the global north and they receive only $10-12 \%$ of their wages.

These are typically low-paid jobs, sometimes below the minimum wage guaranteed by the state, which also means below the subsistence minimum. "The apparel workers who sew a hundred pairs of $\$ 100$ jeans a day will never be able to afford a single pair", writes Collins [2003: 168]. In addition, the working conditions in factories are often unhealthy or dangerous (no ventilation, unsanitary bathrooms, fire hazards, overtime, piece work, child labour, etc.) and women are objects of sexual harassment and even physical punishment [Featherstone and USAS 2002]. The term 'sweatshop' is used for this type of work. The sweatshop work system originated in the 19th century and was characterised by long hours, pay on a piece rate, and very poor working conditions. Nowadays, it usually refers to a workshop located in a global city like New York. Piore [1997] points out that the comeback of the sweatshop was made possible by decreased unionisation and looser government regulations and controls. In a broader sense, the sweatshop also refers to the EPZs and their unhealthy work conditions.

Although the argument has been made that globalisation benefits women because it increases their employment opportunities and economic independence by giving them their own source of income, most scholars usually note how these advantages have been offset by numerous disadvantages. Women have gained employment, but the feminisation of the workforce is associated with the deterioration of working conditions. Women face problems when they try to combine their jobs with with having and looking after a family [Chinkin 2000; Ramamurthy 2001; Rai 
2002; Benería 2003]. Also, outside factory jobs, there are not many other employment opportunities for women; the only other options are usually prostitution or migration to richer countries [Pyle and Ward 2003].

Globalisation processes alter gender systems and relations. Momsen [2004] shows that the traditional gender contract, based on the man's role as breadwinner in the family, is eroding. Not just the relationship between partners is changing, as men and women are changed by increased employment among women, but also the relationship between parents and children is being transformed. In some regions young girls even become the main breadwinner in the family. Increasing unemployment among men forces female relatives to work outside the family. However, their employment does not always guarantee them a higher status in the household. Women are over-burdened by having to occupy two roles, as breadwinner and as the person responsible for the household, while men feel useless and degraded because they sense their dominant position in the household is threatened. In some regions there is a high rate of alcohol abuse and early death among men (e.g. the post-Soviet countries). These changes to gender identities are a source of anxiety for both men and women. The feminisation of work is more a reflection of the weakened role of men than greater economic opportunities for women. Women's paid employment does not automatically lead to social empowerment or gender equality. Even when women work and are successful, this can cause a crisis within the family; and sometimes a woman's independence produces violent reactions from men.

The advent of cheap women's labour has made it possible for many countries in the global south to produce competitive exports. Multi-national corporations are shifting their capital to places where wages can be pushed very low. Freeman [2000] argues that this 'new international division of labour' has been under way since the 1970s. Collins [2003] has shown how the American textile industry has gradually been moving out of the United States to Mexico. In the late 1990s, factories in the southern United States were shut down, workers who had worked there for most of their lives were laid off, and new plants were established in Mexico. However, the garment companies justify their re-location as being based not on the costs of labour but on the purported fact that American women are losing their sewing skills.

This process of re-locating capital is constant. For instance, the first EPZs opened up in Mexico, as one of the first countries to experience them (because of its proximity to the United States), in the 1960s. Later, corporations began to move from the border maquiladoras into central Mexico and to other countries, especially in Central America and the Caribbean, and then to the sweatshops in global cities (even in the First World) and even into a subcontracted informal sector [Louie 2001; Aguilar and Lacsamana 2004], leaving women in some of the former EPZs unemployed.

Louie [2001] has documented how women in the garment sweatshops based in global cities like New York and Los Angeles work in even poorer conditions than what are found in the Third-World EPZs. The First-World sweatshops employ undocumented immigrant workers with no rights and force them to work longer. Nor- 
mal workers work about ten hours a day, but workers without documents work longer and sometimes during the night. In the United States there are now about 22000 garment sweatshops, 7000 of which are in New York City alone. The majority of these sweatshop workers are Chinese and Latin American women. The workers whom Louie interviewed "speak bitterly about how working conditions have declined to 19th century levels because of corporate greed, globalization, and industrial restructuring, and how immigrant bashing has hidden their exploitation". [Louie 2001: 20]

Sweatshops are mostly in the garment industry because it is an industry based on intensive manual labour. The technology of sewing remains essentially the same as it was a century ago. Automatic production methods have not been introduced because the changes in fashion styles and types of material occur rapidly. Sweatshops are easy to start up; the subcontractors can be small companies that only have to buy sewing machines. Supervision is based on a piece-rate system, so the workers are paid according to the number of finished pieces of cloth, not hourly wages. This system makes them work faster. Collins [2003] argues that there is little difference between brand-name and generic products. Production of both cheap and expensive clothing takes place within the same factories using the same technology. The only difference is the quality control - high-end production is controlled more, which puts more stress on the women workers, who are forced to sew more quickly and more precisely.

In the documentaries about women working in EPZs (for instance, The Hidden Face of Globalisation), despite the fact that their working conditions are unhealthy and unsafe, women are shown going to work well dressed, wearing very clean, colourful, and revealing clothes. An explanation for this behaviour is provided by Salzinger [2000], who examined the phenomenon of sexual harassment at work while studying a Mexican electronics factory. She argues that it is because women are also watched and judged according to their appearance. Women workers are under constant visual surveillance and are observed as sexual objects by their male supervisors. Production is associated with a sexualised form of femininity. Women are monitored, but they also monitor one another. The workers compete among themselves to look better. They have to invest considerable energy into their appearance in order to attract the attention of their supervisors and thereby improve their working conditions and wages.

Corporations seeking even cheaper labour are increasingly using the method of subcontracting. Instead of having their own factories they make agreements with other local firms who run smaller shops or employ women working at home. Balakrishnan [2002] calls this form of work the 'hidden assembly line', because the work takes place in the informal sector where there are lower wages, less security, no labour legislation, no formal contracts, and no social benefits. Women usually work more hours than in the factories and are monitored through piece-work quotas. Subcontractors prefer women with children for this work, because of their limited mobility, strong self-discipline, and their need for any form of income in order 
to support their children. Poor women, in order to balance their reproductive role, often accept precarious and vulnerable work [Balakrishnan 2002; Benería 2003]. On the other hand, as Momsen [2004] points out, women with children may prefer this type of job, because they can combine their employment with looking after their children and household in one location.

Subcontracted work at home or in small shops involving family members and neighbours is a form of work in which it is difficult for the workers to organise themselves against exploitative working conditions. Besides the fact that the shop bonds are familial, the workers do not know whom to organise themselves against. They have no information about the corporation that subcontracted their work [Balakrishnan 2002], their employers are usually in a different country, and the big companies just buy the products from the subcontractors and have no responsibility for the workers' working conditions. Women are atomised, working in separate households or in small shops, where it is hard to organise any kind of collective action. However, even in the factories run by multi-national corporations unions are usually prohibited, and if workers are able to organise themselves, the organisations are male dominated and pay no attention to the specific problems women face [Freeman 2000].

Left aside by formal unions, women in EPZs have begun to organise themselves. Collins [2003] gives examples of women's activism in which their organisation is not just centred on the workplace but refers to the wider community. They try to bridge the divisions of work, home, and community in their lives and argue that women are not only workers but also people with other needs. For instance, the Centre for the Orientation of Women Workers in Ciudad Juarez has been organising literacy and health campaigns since the 1970s. Other organisations have focused on reproductive issues, domestic violence, health, and the environment. Through these activities they transcend the boundary between the private and public spheres [Collins 2003].

Louie [2001] describes how Latin American and Chinese women working in New York City sweatshops have organised workers' centres. But she describes another constraint on women's activism in addition to the problems they experience cooperating with unions: the fact that working women also have to look after their children and have barely any free time, and that Chinese women in particular have been taught to obey and not to protest. Activists also fear that they will be fired or blacklisted if they protest. Community-based organisations have helped women workers break out of their isolation, gain new skills, and obtain resources, training, and space in which to meet. Women's activism has led in many cases to solidarity and the empowerment of women.

Women's local activism can be strengthened through cooperation with international movements against sweatshop labour. For example, the Coalition for Justice in the Maquiladoras is active in the United States, Mexico, and Canada. Also, the United Students against Sweatshops has been an influential movement in the United States, and it has been able to help the situation in factories. However, the problem with these international campaigns is that they often portray women work- 
ers as victims of globalisation and ignore their agency [Featherstone and USAS 2002]. Benería [2003] warns against 'the women as victims approach' in the study of gender and globalisation. In her view, it is important also to see the improvement in their lives, their increased autonomy, and activism.

As Balakrishnan [2002] and Collins [2003] note, international campaigns may also harm workers. Boycotting products can lead to job losses among women if the factories close and leave the region. Even though women are not paid enough, they at least have some income. Both authors argue that international activists should pay more attention to what the workers need and demand that firms be accountable to the local community. They also argue that while the corporations may show an interest in improving working conditions in the aftermath of protests, they will never be interested in changing their basic goal, which is to increase profit through cheap labour.

\section{Global feminised care work and migration}

Two interconnected phenomena, care work and migration, are feminised on a global scale. Care or domestic work performed by women from developing regions in Western Europe and the United States typically involves long working hours, low income - often below the minimum wage - and a high level of abuse and sexual harassment. Immigrant women, some of them illegal immigrants, are preferred over local women in these jobs because they can be paid less and exploited. Studying domestic workers Hondagneu-Sotelo [2001] divided them into three categories: live-in nannies/housekeepers, live-out nannies/housekeepers, and housecleaners (the last of these is the best paid and considered more of a contract arrangement). Domestic work is not regarded as a normal job by either the workers or their employers. There is a social stigma attached to it. It is not well paid because it is performed in the private sphere and is feminised. Parreñas [2001] distinguishes the following types of domestic work: childcare, housecleaning, and care for the elderly. She points out that women migrants in these 'unskilled jobs' often have college degrees, but their income is higher than what it would be if they worked in their profession in their home country. For them, migrating to a foreign country means downward mobility and inconsistent social status. As Sassen [2002] notes, this type of work is not unionised and workers have no rights, such as the right to take sick leave. It is difficult to organise and demand better conditions because the women are isolated in separate households, and they are held back because of their gender and sometimes their illegal status.

In Global Woman, Ehrenreich and Hochschild [2002: 17, 22] argue that a global transfer of care and love from the Third World to developed countries is occurring. Hochschild calls this process a 'care drain' and a 'global heart transplant'. Women from poor countries migrate in order to work as nannies and maids for middle-class families in which both partners are working. Migrant women are surro- 
gates providing the care that affluent mothers have no time to give to their children. Meanwhile, most migrant women leave their own children at home and may not see them for many years, while they usually just send money to support them and finance their education.

A number of authors have documented the stories of these women, who feel the pain of family separation [Parreñas 2001]. They miss their own children, and the children they care for often become the object of the love they cannot give to their own children. Many children that are abandoned by their migrant mothers are cared for by other family members instead, usually grandmothers or aunts; men do not usually replace absent mothers. Children left behind tend to have emotional problems, are more frequently ill, have no one close to confide in, and many of them have problems at school and are more aggressive [Parreñas 2001; Ehrenreich and Hochschild 2002; Benería 2003].

According to Hondagneu-Sotelo [2001], globalisation has increased the amount of migration among women. Migration flows are directed mostly towards the United States and Western Europe, but also to newly industrialised countries in Asia (such as Taiwan) and the oil-rich Middle East. Most migrant women come from the Caribbean, Mexico, Central America, Peru, Sri Lanka, Indonesia, Eastern Europe, or the Philippines (the Filipino women are described most). The key factors driving migration are wage inequalities and the differences in wealth between regions. Women migrate because of poverty in their home country. As Hochschild notes, "migration has become a private solution to a public problem". [2002:18]

Eastern Europe is a source of domestic labour mainly for Western European countries. The market for a specific type of domestic work - au pairs who are usually young, childless students migrating for a short time - has been growing since the mid-1990s. Hess and Puckhaber [2004], studying au pairs migrating from eastern Slovakia to Germany, argue that, although au pair programmes are promoted by agencies as a cultural exchange, the reality and experience of au pairs shows that this job is just another word for domestic work occurring in conditions similar to those experienced by live-in domestic workers. Au pairs usually expect that they will only have to help out with a few tasks, that they will be treated as a member of the family, and that they will have time to learn the language. However, they are often disappointed and find themselves overwhelmed with a heavy workload, looking after the children and the housework, performing monotonous and boring work, and with little free time, while their use of space, food, and hygiene facilities is monitored and limited. For German parents, employing an au pair is a convenient strategy for balancing work and family duties. However, Willams and Baláz [2005], who have analysed various types of migrants from Slovakia to the United Kingdom, have shown that au pairs benefit from their stay with the host family, and in addition to being able to save some money they most value the opportunity to improve their English, experience life in a foreign country, and raise their self-confidence and independence. By improving their language skills they have better chances of being able to study or start their own business when they return home. Lutz [2002] has 
shown how domestic workers from Poland perceive these low-skilled jobs as just temporary solutions and as a transformational tool for future life. According to Lutz, women migrants can be positively considered as 'agents of change' promoting new, international lifestyles.

Women from developing countries are also very important financially for the states that are dependent on the money that migrants send home. According to Ramamurthy [2001], states count on this income as part of their development strategy. "The growing immiserization of governments and economics in the global south is one such condition, insofar as it enables and even promotes the migration and trafficking of women as a strategy for survival." [Sassen 2002: 273] The Philippines are an extreme example. Sassen describes how the country's primary export item is care. Promoting migration of care workers and also sex tourism is a way of dealing with unemployment and eliminating debt.

Not only developing countries in the Third World are dependent on the 'invisible' work of women, but, according to Sassen [2002] and Parreñas [2001], the entire economy of the post-industrial society would be unable to function without domestic servants, nannies, and sex workers. In this context, Litt and Zimmerman refer to a "new world domestic order: in which the increasing domestic and childcare needs in affluent nations are filled by vulnerable and low-paid immigrants from developing countries". [2003: 158]

A pair of combined factors lies behind the migration of women for domestic jobs: on the one hand, it is the poverty in the women's home countries, and on the other it is the 'care deficit' caused by the employment of middle-class women, who are unable or unwilling to care for their own children and elderly relatives [Ehrenreich and Hochschild 2002]. Life in global cities, like New York and London, where there is a concentration of highly educated professionals living in two-career households with children, depends on the services of low-wage immigrants working in restaurants, hotels, households, and childcare. Sassen argues that "women, so often discounted as valueless economic actors, are crucial to building new economies and expanding existing ones". [2002: 256] Hondagneu-Sotelo [2001] also points out that in global cities the inequality between high-end professionals and low-paid workers is sharpening.

There is a link between women from affluent countries and the immigrant women they employ. The fact that nannies and maids are available and are usually cheap enables women from the global north to pursue their careers. As HondagneuSotelo [2001] and Ehrenreich and Hochschild [2002] have pointed out, care work still rests on women's shoulders, only now it is the shoulders of women subordinated by class and race. Men have not started to participate more in domestic responsibilities; their privileges within the family have remained intact [HondagneuSotelo 2001; Ehrenreich and Hochschild 2002]. Not only are men still not caring for children any more than they were before, but countries, especially the United States, are often cutting back on public childcare services.

This is associated with the overall diminishing role of the state amidst globalisation and especially with the end of the welfare state brought on by imposed neo- 
liberal policies. Women are particularly affected by cuts in social spending, as it is women who make up for the absence of state social services. As Ramamurthy [2001] and Litt and Zimmerman [2003] argue, it is especially the structural adjustment policies that have harmed women. Starr [1994] has explained how the structural adjustment programmes are associated with loans from the IMF and the World Bank, which, when lending money to developing countries to alleviate a debt crisis, have simultaneously promoted free-market policies and forced developing nations to reorganise their economies by means of privatisation, by opening up the domestic economy to international markets, and by reducing government control. The argument was that capitalist growth would alleviate poverty in Third World countries. Structural adjustment loans have especially been linked to cuts to subsidies for products and services (water, electricity, education, medical care, and public transport). Starr argues that there is a gender bias to these policies, based on egoism, profit-seeking and free market ideology. Women's unpaid work in the household remains invisible to economic theory and policy. However, the assumption is that this unpaid women's work is what will replace the state services that have been eliminated. Poor women especially have to work longer hours than before, both at home and they also seek other forms of employment outside of the household [Rai 2002; Sassen 2002].

Another effect that welfare cutbacks have on women is that women are more often benefit recipients [Pyle and Ward 2003]. The struggle of women to make a living is often the source of more health problems, which are in many places no longer covered by state medical care [Denis 2003]. The shrinking welfare state also affects women in that in many countries they are often employed in social services, and with the cut-backs they are losing their jobs.

\section{Conclusion}

Both the theories of globalisation and actual globalisation projects, especially the most influential one - neo-liberalism - are masculinised. It is mostly women who bear the increased burden that results from the diminishing role of the state under globalisation. They have to replace social services when state welfare benefits are cut. Not only domestic work has been re-organised, but globally productive labour has also changed. Factory production has not disappeared but has been globalised. The global economy is dependent on women's labour; both in the global south, where assembly-line export-production zones have emerged, and in the First World, especially in big cities that depend on cheap immigrant labour. Globalisation affects men and women differently; while the global political and corporate elites are mostly men, production, dependent on flexible and precarious employment, is mainly filled with women. The neo-liberal globalisation project exploits gender stereotypes and takes advantage of women's labour owing to the fact that it tends to be cheaper and women are less likely to be organised in unions. 
Not only does globalisation profit from gender stereotypes but it also changes gender systems because it leads to migration and new employment opportunities for women on a global scale. Women from developing countries migrate to obtain domestic jobs in the First World. Globally, care work is performed by women, and between women themselves inequalities are growing. Families and gender roles are changing, but not always towards greater gender equality. Globalisation alters gender regimes by re-arranging the division of labour of men and women.

Not all dimensions of globalisation are examined to the same extent, and economic globalisation and changes affecting labour tend to receive the most attention. The political, cultural, environmental, and psychological aspects of globalisation from a gender perspective should be analysed more in future research. I suggest that Czech academia pay more attention to the specific gender effects of globalisation and examine the empirical effects of these issues in a post-socialist country.

MARTA Kolářová is a PhD candidate in the Department of Sociology, Faculty of Social Sciences, Charles University, where she teaches a course on globalisation. She works at the Institute of Sociology, Academy of Sciences of the Czech Republic. She studied gender studies at Sussex University in the UK and at Rutgers University in the US on a Fulbright Scholarship.

\section{References}

Afshar, Haleh and Stephanie Barrientos. 1999. Women, Globalization and Fragmentation in the Developing World. London: Macmillan Press.

Aguilar, D.D. and A.E. Lacsamana. 2004. Women and Globalization. New York: Humanity Books.

Balakrishnan, Radhika. (ed.) 2002. The Hidden Assembly Line: Gender Dynamics of Subcontracted Work in a Global Economy. Bloomfield: Kumarian Press.

Benería, Lourdes. 2003. Gender, Development, and Globalization. New York: Routledge.

Bergeron, Suzanne. 2001. 'Political Economy Discourses Of Globalization and Feminist Politics.' Signs 26 (4): 983-1007.

Bhagwati, Jagdish. 2004. In Defense of Globalization. New York: Oxford University Press.

Chinkin, Christine. 2000. 'Gender and Globalization.' United Nations Chronicle 37 (2): 69-70. Available at: <http://www.un.org/Pubs/chronicle/2000/issue2/0200p69.htm>.

Collins, Jane L. 2003. Threads: Gender, Labor, and Power in the Global Apparel Industry. Chicago: The University of Chicago Press.

Connell, R. W. 1998. 'Masculinities and Globalization.' Men and Masculinities 1 (1): 3-23.

Danner, Mona and Gay Young. 2003. 'Free Markets and State Control: A Feminist Challenge to Davos Man and Big Brother.' Pp. 82-90 in Women Reinventing Globalization, edited by J. Kerr and C. Sweetman. Oxford: Oxfam GB.

Denis, Ann B. 2003. 'Globalization, Women and (In)equity in the South: Constraint and Resistance in Barbados.' International Sociology 18 (3): 491-512.

Ehrenreich, Barbara and Arlie R. Hochschild. 2002. Global Woman: Nannies, Maids, and Sex Workers in the New Economy. New York: Metropolitan Books. 
Enloe, Cynthia. 1990. Bananas, Beaches, and Bases: Making Feminist Sense of International Politics. Berkeley: UC Press.

Featherstone, Liza and USAS. 2002. Students against Sweatshops. New York: Verso.

Freeman, Carla. 2000. High Tech and High Heels in the Global Economy. Durham \& London: Duke University Press.

Freeman, Carla. 2001 'Is Local: Global as Feminine: Masculine? Rethinking the Gender of Globalization.' Signs 26 (4): 1007-1038.

Giddens, Anthony. 2000. Unikající svět. Prague: Sociologické nakladatelství (Czech edition of the original Runaway World. London: Profile Books. 1999).

Hess, Sabine and Annette Puckhaber. 2004. “"Big Sisters” Are Better Domestic Servants?! Comments on the Booming Au Pair Business.' Feminist Review 77 (1): 65-78.

Hochschild, Arlie R. 2002. 'Love and Gold.' Pp. 15-30 in Global Woman, edited by B. Ehrenreich and A. Hochschild. New York: Metropolitan Books.

Hondagneu-Sotelo, Pierrette. 2001. Domestica: Immigrant Workers Cleaning and Caring in the Shadows of Affluence. Berkeley: University of California Press.

International Monetary Fund. 2002. Globalization: Threat or Opportunity? <http://www.imf.org/external/np/exr/ib/2000/041200.htm> (accessed Dec. 2003).

Kerr, Joanna and Caroline Sweetman. (eds.) 2003. Women Reinventing Globalisaton. Oxford: Oxfam GB.

Kelly, Rita M., Jane H. Bayes, Mary Hawkesworth and Brigitte Young. (eds.) 2001. Gender, Globalization, and Democratization. New York: Rowman \& Littlefield.

Kimmel, Michael S. 2003. 'Globalization and Its Mal(e)contents: The Gendered Moral and Political Economy of Terrorism.' International Sociology 18 (3): 603-620.

Litt, Jacquelyn S. and Mary K. Zimmerman. 2003. 'Global Perspectives on Gender and Care Work.' Gender \& Society 17 (2): 156-165.

Louie, Miriam C. Y. 2001. Sweatshop Warriors: Immigrant Women Workers Take on the Global Factory. Cambridge, MA: South End Press.

Lutz, Helma. 2002. 'At Your Service Madam! The Globalizaton of Domestic Service.' Feminist Review 70 (1): 89-101.

Marchard, Marianne H. and Anne S. Runyan. (eds.) 2000. Gender and Global Restructuring. New York: Routledge.

Mezřický, Václav (ed.) 2003. Globalizace. Prague: Portál.

Momsen, Janet H. 2004. Gender and Development. New York: Routledge.

Parreñas, Rhacel S. 2001. Servants of Globalization: Women, Migration and Domestic Work. Stanford: Stanford University Press.

Peterson, V. Spike and Anne S. Runyan. 1999. Global Gender Issues. Oxford: Westview Press.

Piore, Michael. 1997. 'The Economics of the Sweatshop.' Pp. 135-142 in No Sweat: Fashion, Free Trade, and the Rights of Garment Workers, edited by A. Ross. New York: Verso.

Pyle, Jean L. and Kathryn B. Ward. 2003. 'Recasting our Understanding of Gender and Work during Global Restructuring.' International Sociology 18 (3): 461-489.

Rai, Shirin M. 2002. Gender and the Political Economy of Development. Cambridge: Polity Press.

Ramamurthy, Priti. 2001. 'The Gendered Politics of Economic Globalization.' An On-line publication. Available at: <http://w3.arizona.edu>. Tucson: University of Arizona.

Renzetti, Claire and Daniel J. Curran. 2003. Ženy, muži a společnost. Prague: Karolinum. (Czech edition of the original Women, Men, and Society. Boston: Allyn \& Bacon. 1999)

Rowbotham, Sheila and Stephanie Linkogle. 2001. Women Resist Globalization. London: Zed Books.

Salzinger, Leslie. 2000. 'Manufacturing Sexual Subjects: "Harassment", Desire and Discipline on a Maquiladora Shopfloor.' Ethnography 1 (1): 67-92. 
Sassen, Saskia. 2002. 'Global Cities and Survival Circuits.' Pp. 254-274 in Global Woman, edited by B. Ehreinreich and A. Hochschild. New York: Metropolitan Books.

Starr, Pamela. (ed.) 1994. 'What Is Structural Adjustment?' Pp. 1-12 in Mortgaging Women's Lives: Feminist Critiques of Structural Adjustment, edited by P. Starr. London: Zed Books.

Stiglitz, Joseph. 2002. Globalization and Its Discontents. New York: WW Norton \& Company.

True, Jacqui. 2003. Gender, Globalization, and Postsocialism: The Czech Republic after Communism. New York: Columbia University Press.

Walby, Sylvia. 1997. Gender Transformations. New York: Routledge.

Wichterich, Christa. 2000. Globalizovaná žena. (The Globalised Woman) Prague: proFem.

Willams, Allan W. and Vladimir Baláz. 2005. 'What Human Capital, Which Migrants?

Returned Skilled Migration to Slovakia from the UK.' The International Migration Review 39 (2): 439-469. 